\title{
Analysis on Cooperation between Banks and Insurance Companies in China Rural Areas
}

\author{
Gujun Yan \\ Department of Finance, Zhejiang University, \\ Hangzhou, P. R. China 310027 \\ Email: zjujt@163.com
}

\begin{abstract}
Cooperation between banks and insurance companies, and the credit insurance intervention by insurance companies for the peasant household's loan underwriting, are beneficial to reduce the risks in rural financial institutions' lending business, thus increase the effective supply of agricultural credit. From the perspective of actual operation, there still exist such problems as the appearance of bank-insurance cooperation, the singleness of insurance type and the imperfect claim settlement mechanism in rural areas of China. In order to further promote the establishment of the interactive mechanism of banking and insurance, it is necessary to broaden the scope of the protection of credit insurance, to foster insurance companies and credit institutions to form risk-benefit communities, to advance policy support and subsidies in respects of taxes and premiums, and to construct the commercial operation mode of rural credit insurance under the government support.
\end{abstract}

Keywords-Microcredit, Insurance company, Peasant household, Risk sharing mechanism, Credit risk

\section{INTRODUCTION}

Due to the weak nature of agriculture, rural financial organizations involved in agricultural credit is faced with great risk. To this end, we should actively carry out the innovation of bank-insurance cooperation and introduce insurance services into the rural microfinance chain. The effective combination of rural micro-credit and insurance, thus to provide insurance service and support for credit risk in micro-credit, on the one hand, can make up for the shortage of mortgage and collateral of peasant household, bring explicit credit increment to peasant household, and enlarge insurance service field of the insurance company; on the other hand, can set up a second risk protection network for microcredit institutions. So, that may help to realize the multi-party win-win situation among farmers, micro credit institutions and insurance companies, and ultimately increase the effective supply of agriculture-related credit.

\section{The Combination of Rural Micro-Credit and INSURANCE: EFFECTS ANALYSIS}

\section{A. Help rural financial organizations to effectively prevent credit risks}

Rural financial organizations mainly take rural low-income population as the service objects. Restricted by the system and so on, this kind of objects lacks the loan collateral. If the loans of rural financial organizations are guaranteed only by the personal credit of the rural low-income people, it will often face the moral risks from the borrowers. At the same time, agricultural production is vulnerable to systemic risks, such as bad weather, so that farmers ' income is not very stable. The volatility of the income of peasant households also determines that there is a big credit risk in lending of rural financial organizations. The above situation not only leads to insufficient supply of rural credit, but also restricts the sustainable development of rural financial organizations.

If rural microfinance and insurance cooperate and interact, to enable the farmers to hold credit insurance and take the insured amount as collateral, the rural financial organizations who are beneficiaries can obtain the insurance indemnity as the repayment of the loan when risk accidents happen (such as the accidental death of a farmer, the inability to pay for disability or natural disasters, etc.). This can transfer some of the loan risks of rural financial organizations to the insurance institutions, improve their expected income and increase the enthusiasm of their loans to farmers. In addition, the cooperation between insurance and credit can also increase the intermediary business income of rural financial organizations and enhance the operating efficiency.

\section{B. Conducive to improve the anti-risk ability of farmers to ease the problem of farmers' difficulty in lending}

The long period of agricultural production, the weak ability to resist natural disasters, the price changes of agricultural products and the price increases of production materials, all will increase the uncertainty of expected income of farmers. At the same time, the level of social security in rural areas still needs to be improved. When there are major diseases or disabilities in the loan households, it is often difficult to avoid the phenomenon of "causing poverty due to illness and returning to poverty due to illness."

If microcredit and insurance co-operate effectively to reduce the risk of loan households failing to make repayments due to accidental accidents, farmers will be able to receive some compensation when they are in an accident. This will effectively reduce the possibility of returning to poverty of loan households, reduce the repayment pressure of their families, and help farmers solve their worries. Furthermore, through the introduction of the micro-credit insurance mechanism, the farmers can purchase the insurance and act as the collateral for the financing, so that the lending institution can obtain compensation from the insurance company with the policy value when insured peasant households suffer from the 
accident, which will help improve the credit rating of the lending households and promote farmers' loan availability. Moreover, under the action of microcredit-insurance mechanism, as the risk of financing to farmers in lending institutions is reduced, the lending rate will also be leveled off, which will also reduce the cost burden of financing for rural households.

\section{Help insurance institutions to excavate the rural insurance market}

Faced with increasingly fierce competition in the industry, insurance companies urgently need to expand their business scope and seek new business growth points. Relatively speaking, rural insurance market in our country is still relatively weak, and the potential of this market is huge with more business opportunities. For future business expansion of the insurance industry, the expansion of rural insurance business and market share has become the basic choice.

However, due to the scattered distribution of rural residents and the backward infrastructure in rural areas, the direct development of rural insurance market by insurance companies is also constrained by factors such as the high cost of business outlets construction and the difficulty of customer information collection. The cooperation between insurance companies and rural financial institutions can effectively solve the problem of the construction of insurance sales platform by using the latter's network resources, alleviate the pressure of the high cost of rural insurance sales, increase premium income and speed up the penetration into the rural market. In addition, because rural financial organizations have accumulated a lot of information about the main body of the rural economy in the process of carrying out microfinance, the cooperation between two sides and through the feedback of business-related information by rural financial organizations, also facilitate insurance agencies to further develop the rural insurance market, expand agriculture-related insurance products and other insurance services.

\section{Main Problems in the DeVelopment of Microcredit INSURANCE AT PRESENT STAge}

In recent years, various practices in our country have been carried out on the cooperation and interaction between insurance and microfinance, such as "peasant household loans + personal accidental injury insurance" in Shandong province, "insurance + credit + government subsidies" in Xinjiang, and "policy-oriented agricultural insurance + preferential credit interest rates” in Guangdong province. However, judging from the actual operation, there are still some problems such as the low level of bank and insurance cooperation, monotonous insurance products, and the inadequate claim settlement mechanism.

\section{A. Mere formality of the mechanism of bank and insurance corporation}

At present, most insurance companies and rural microfinance institutions cooperate with each other in the form of relatively loose agreement agents, and the cooperation between the two parties is superficial. Farmer-related financial institutions only regard insurance agency as a new source of agency fees instead of scrutinizing the applicant's insurance conditions. Insurers also rely solely on agricultural financial institutions to sell insurance products to expand their business. The two parties are relatively loose stakeholders. The mutual benefit of both sides is insufficient and the risk-interest community cannot be formed. Therefore, both the insurance companies and the rural microfinance institutions do not take this kind of cooperation as their own important business strategy, and the two sides do their own work according to the inherent logic and actual needs of their own development, rather than establish the deep cooperation mechanism from the inherent requirement of the whole rural financial market development $[1 ; 2]$.

Because credit and insurance do not have a long-term common interest mechanism, the level of agency fees directly determines the choice of cooperative insurance companies and the sales of insurance products by the financial institutions involved in agriculture, prompting the insurance companies to alternately increase the viciousness of fees competition. In addition, in the current cooperation relationship between credit and insurance, insurance was generally involved after the object of credit, conditions and quotas had been determined. In many cases, the randomness of the purchase of small insurance is very large, and not as a major reference factor of credit rating, which also limits the enthusiasm and innovation of insurance companies [3].

\section{B. The insurance variety being single and the scope of insurance being small}

Farmers and rural small and micro businesses will use loans for agricultural production and management activities. In the process, they may face many risks such as personal risk, natural risk, business risk and so on. However, the existing micro-credit insurance business is mainly limited to the mode of "micro-credit + accidental injury insurance"[4; 5]. Only when the borrower is in an accidental death or disability, the insurance company pays as insurance liability. This is conducive to the insurance companies to avoid risks, but makes the coverage limited. At the same time, although the underwriting liability has the difference of death, disability and so on, most of the borrowers choose the basic protection type of death and total disability based on controlling the financing cost. The comprehensive protection which can play a more important role often has little choice, which leads to further weakening of the security function. In reality, there are still gaps in the insurance of farmers' inability to repay due to natural disasters, which makes the source of risk and insurance coverage does not match, and hard to avoid credit defaults caused by natural disasters and other factors.

\section{The level of insurance services needs to be improved}

Microfinance insurance usually adopts cooperative-agent mode, and the loan officer of the agricultural financial institution is the agent of such insurance. However, grass-roots loan officers usually do not have systematic and standardized insurance business operation procedures and professional training, and their insurance business knowledge is generally relatively scarce. In particular, they are not sufficiently aware of the contents and clauses of insurance policies and the degree of protection of the insured's interests. It is difficult for the borrower to provide insurance related consulting services. 
Some loan officers, in order to improve sales performance, even blindly sell, so that borrowers passively handle the insurance. At the same time, insurers have the problem of over-claims and over-efficiency when they make payments, which are manifested in the complicated procedures for identifying disabled persons, the gradual approval system and the strict procedures of claims settlement.

Also, farmers are not fully aware of the insurance company's business rules and not pay attention to promptly collect the claims material after the accident, causing the exceeding of the claim period, and triggering insured farmers' resentment against the insurers.

Furthermore, China's insurance institutions have fewer outlets in the township area below the county level, which leads to the difficulty of providing complete services at close range. Farmers often need to travel to and from the urban and rural areas for many times to handle claims and other matters.

\section{The policy support has not been in place, and the willingness of farmers to participate in insurance not strong}

Micro-credit insurance has the nature of quasi-public goods, which requires the government to stimulate the enthusiasm of all relevant parties through such measures as tax incentives, premium subsidies, interest rate concessions and relaxation of reserve requirements. However, China's microfinance insurance business is basically in line with the commercial insurance treatment. There are no additional supportive measures [6; 7]. Generally speaking, it is in the state of institutional cooperation and voluntary participation of households. The government intervenes only through distributing some non-mandatory documents to encourage the relevant subjects to participate in the insurance.

Due to insufficient government support, insurers lack the motivation to participate in this market, which is riskier and more costly. On the other hand, for farmers and small and micro businesses, they need to pay premiums when they are insured, and the premium is borne by them. In addition to the cost of loans, premium expenses bring about an increase in the cost of capital. In addition, the risk awareness of rural economic entities is weak, the cognition level of insurance is relatively low, and the potential benefits of insurance is not fully realized, which leads to low participation in insurance by rural households.

\section{Path InNovation of The Cooperative Development of} RURAL MiCROFINANCE AND INSURANCE

The cooperation and interaction between insurance and credit can effectively avoid the credit risk of financial institutions involved in agriculture, expand the scale of lending, and then help to solve the problem of farmers' loan difficulty which has long puzzled the development of rural economy in China. In view of the problems existing in the cooperative development of "credit + insurance", it is necessary to improve following aspects in order to further promote the establishment of banking-insurance interaction mechanism:

\section{A. To speed up product development and broaden the scope of credit insurance coverage}

After in-depth study of the market, bankers and insurance companies should develop a series of microfinance insurance products that are close to the rural reality and consistent with the actual needs of farmers, so as to cover as much as possible the risks that affect the repayments of farmers. In reality, when lending to farmers, it is most common for farmers to fail to repay full repayments due to property losses. Therefore, based on the existing "micro credit + accidental injury insurance", we should gradually enrich product categories, expand the scope of protection, and develop "micro credit + property insurance" products under the support of government policy. By using this kind of product, farmers can insure the crop insurance or livestock insurance and so on. When farmers encounter the insurance accident causing property losses and repayment difficulties, the insurance company may give corresponding compensations, so that farmers' repayment ability can be guaranteed.

In the meantime, for households that have some sources of stable income and need short-term financing to deal with such matters as weddings and funerals, we need to design and launch the product form of "microcredit + life insurance". With life insurance policy as a pledge to loan, insurers can use the cash value of the policy to repay the principal and interest of the loans owed by the farmers when the latter cannot repay the loan. In addition, we should also explore the form of "microfinance + guarantee insurance" to improve the credit level of farmers and control the loan recovery risk of the lending institutions [8].

\section{B. To strengthen the collaboration between insurance companies and rural microfinance institutions}

Rural credit institutions should strengthen communication and cooperation with insurance companies, so that insurance companies can design and develop particular types of insurance that match with agricultural credit products on the basis of familiarity with the credit audit conditions of credit institutions. In particular, when the borrower applies for a loan, in order to improve the credit rating of the borrower and to use the risk control experience of the insurance institution, the insurers should intervene as soon as possible to provide the targeted product according to the specific circumstances of the borrower, thus to support the credit institution to reasonably determine the credit conditions and credit lines, and to promote to form a community of risk \& interest between insurance companies and rural credit institutions. Credit institutions should give full attention to the role of microcredit insurance in promoting their own development. They should use the large amount of customer information they hold to promote the sales of the small-sum insurance products; and the method that the agency commission renewal fee is regularly paid according to the expired premium amount should be adopted to form bank-insurance risk sharing mechanism for both parties.

Moreover, we should try to introduce the mechanism of subrogation recovery. If the borrowers have the repayment ability, the insurance agency can make the corresponding subrogation right, so as to facilitate the long-term development of the cooperation between banks and insurance companies. 


\section{To increase policy support}

The establishment of rural bank-insurance interaction and cooperation mechanism is inseparable from the support and promotion of the government. Especially, the microcredit insurance is essentially a kind of financial product aimed at the vulnerable groups in rural areas. With the nature of quasi-public goods, its promotion must be guided and supported by the government.

To this end, the government should moderately reduce the sales tax on insurance institutions engaging in rural microfinance insurance business, so as to encourage insurance companies to expand the rural insurance market and raise the level of insurance coverage for agricultural credit. At the same time, we can enlarge the scope of premium subsidy and subsidize the farmers who buy the credit insurance, in order to reduce the cost of insurance and increase the penetration rate of insurance. In addition, it is appropriate to relax the conditions for write-off of bad debts in rural microfinance institutions and give preferential policies such as differential deposit reserve requirements to facilitate microfinance institutions to provide preferential treatments in terms of lending procedures and lending rates, and to increase farmers' enthusiasm for purchasing insurance. In short, through the government's policy support and subsidies in terms of taxes and premiums, the formation of the commercial operation mode of rural credit insurance under the government support, will facilitate the "credit + insurance" model to cover the demand subjects to a greater extent and achieve sustainable development.

\section{To improve the service ability of microcredit insurance}

Firstly, insurers should step up their guidance on the insurance business in rural MFIs so that the agent can understand the normative business procedures and ensure the operation standard of the agency business. At the same time, the local insurance regulatory agency or the insurance association should grant the "qualified insurance agent" qualification certificate to the trained authorized agents, and do well in the control of the agent qualification. Secondly, the efficiency of claims should be improved. Insurance companies should address the actual situation in rural areas, reasonably simplify the claims process, open up a green channel for claims settlement of micro-credit insurance, and actively assist farmers in handling claims and settlement procedures to protect the interests of insurance consumers. Thirdly, it is necessary to encourage insurance companies to set up new outlets in villages and towns, assign special persons to take charge of network services, and really go deep into rural areas, so as to improve insurance company's operation ability and service level in the rural micro insurance market.

\section{E. To step up publicity and promotion to foster farmers ' awareness of insurance}

Rural borrowers' cognition of insurance products is an important factor that affects the demand for microcredit insurance products. Because of the uneven knowledge level of farmers and the lack of insurance outlets, the products of insurance companies are often little known in rural areas.
Therefore, in combination with the typical payment examples in the reality, we should further strengthen the publicity, to promote farmers and other rural economic subjects to understand the risks and insurance, to help them to accept the modern insurance concept, to cultivate their insurance enthusiasm, and to make insurance products gradually into the ranks of rural residents' daily purchase. In order to enhance the effectiveness of publicity, the insurance company should strengthen the cooperation with the rural microfinance institution and Village Committee. By making use of the popularity and geographical advantages of the latter, it may help to publicize and promote the credit insurance products widely, and guide the borrowers to insure actively according to the actual risk situation.

\section{Conclusion}

The credit insurance intervention by insurance companies for the peasant household's loan underwriting, are beneficial to reduce the risks in rural financial institutions' lending business. In order to further promote the establishment of the interactive mechanism between banking and insurance, it is necessary to publicize and promote the credit insurance products, to advance policy support and subsidies in respects of taxes and premiums, to construct the commercial operation mode of rural credit insurance under the government support, and to form a community of risk-interest between insurance companies and rural credit institutions.

\section{ACKNOWLEDGMENT}

This work is financially supported by special projects of liberal arts of Zhejiang University.

\section{REFERENCES}

[1] Liang, Lili, 2016. Bank-Insurance Cooperation to Promote the Innovation of Cooperative Mechanis m for Financial Poverty Alleviation, Northern Economy and Trade, No.12, pp.112-113.

[2] Yang, Mingwan, 2017."Sanshui Model": the practice and exploration of the cooperative agricultural loan model of "government-bank-insurer" under the Framework of Rural Financial Inclusion, South China Rural Area, No.2, pp.4-9.

[3] Li, Zhiyong, 2016. Developing bank-insurance cooperation under the new economic normality to solve the financing dilemma of small \& micro enterprises in rural areas, Agricultural Economy, No.5, pp.100-101.

[4] Li, Lanfeng, 2014. Research and Suggestions on the Development of Rural Microfinance Insurance, Shanghai Insurance, No.5, pp.12-16.

[5] Yang, Han, 2015.Analysis of the Develop ment of Mic rocredit Insurance Business in Shaan xi Province from the Perspective of Inclusive Finance, Western Finance, No.3,pp.75-79.

[6] Li, Wenzhong, 2014.The Role of Micro-credit Guarantee Insurance in Alleviating the Financing Difficulty of Small and Micro Enterprises, Insurance Studies, No.2, pp.75-84.

[7] Liu, Suchun, 2017. A Research on Coupling and Coordinated Development between Agricultural Insurance and Agricultural Credit, Insurance Studies, No. 2, pp.29-39.

[8] Cai, Leiyuan, 2014. Research on the Risk Prevention of Small Loan Guarantee Insurance, Market Forum, No.8,pp.45-47. 